\title{
The South China Sea Disputes: An Opportunity for the Cross Taiwan Strait Relationship
}

\author{
Yen-Chiang Chang
}

The South Sea, also called the South China Sea, is a semi-enclosed marginal sea in the Pacific Ocean. It is located north of China and the island of Taiwan, east of the Philippines, south of Kalimantan Island and Sumatra Island and west of the Malay Peninsula and the Indo-China peninsula. States and territories with borders on the South China Sea, include mainland China, Taiwan (China), Vietnam, Malaysia, Singapore, Indonesia, Brunei and the Philippines. ${ }^{1}$

The total area of the South China Sea is 350 square kilometres. The South China Sea contains over 230 small islands, atolls, cays, and shoals, collectively known as the South China Sea islands. These islands are geographically divided into four parts: the Paracel Islands, the Macclesfield Bank, the Pratas Islands and the Spratly Islands. Most of these islands are very small, the largest of which is Pratas, with 12 square kilometres and Itu Aba Island, the largest island of Spratly Islands, is also only 0.4 square kilometres in size. ${ }^{2}$

Territorial disputes on the South China Sea islands began in the mid-late 2oth Century. Since the 1970s, neighbouring countries in the South China Sea, such as Vietnam, the Philippines and Malaysia, began to conduct activities in the South China Sea islands and claim sovereignty over the Spratly Islands, for the following two reasons. On the one hand, the South China Sea is rich in natural resources including oil, gas and fish. On the other hand, the South China Sea, as a strategic road connecting the Pacific Ocean and Indian Ocean and a major shipping lane connecting Asia and Oceania, Europe and Africa,

1 Chao Ma, On the Island System and the International Maritime Delimitation (Master's thesis, Guizhou University, May 2007) at 28.

2 Lihai Zhao, On the South China Sea Islands, A Number of Legal Problems, 4 LAW AND Social Development 50 (1995); Jianming Shen, International Law Rules and Historical Evidences Supporting China's Title to the South China Sea Islands, 21 Hastings International AND Comparative LaW Review 2 (1997-1998).

(C) YEN-CHIANG CHANG, 2019 | DOI:10.1163/9789004379633_004

This is an open access article distributed under the terms of the prevailing CC-BY-NC License at the time of publication. 
plays a significant role in national defense and economics. ${ }^{3}$ The 1982 United Nations Convention on the Law of the Sea (hereinafter UNCLOS) sets up the legal systems for a continental shelf and exclusive economic zones. ${ }^{4}$ Article 121 of UNCLOS states that as long as territory can sustain human habitation or economic life of their own, they shall have a corresponding continental shelf and an exclusive economic zone. This provision will undoubtedly broaden the scope of jurisdiction of a State, expand its economic interests gained by using the sea ${ }^{5}$ and potentially aggravate the rivalry for activities on and sovereign rights over, the South China Sea, among States surrounding it.

In recent years, rivalry for the South China Sea has become increasingly intense among surrounding States. In addition, Southeast Asian States have tried to involve the United States, Japan and other States, apparently in order to make the South China Sea disputes more international and a potentially more complex issue. ${ }^{6}$ On 17 February 2009, the Congress of the Philippines enacted the Philippine Baselines Law, which classifies the Spratly Islands and Scarborough Shoal, 'as a regime of islands under the Republic of Philippines'. On 5 March 2009, the Malaysian Prime Minister, Abdullah Ahmad Badawi landed on Swallow Reef and claimed sovereignty over the reef and its adjacent waters. On 8 March 2009, the USNS Impeccable conducted monitoring activities, without the authorization from the Chinese government, within the Chinese exclusive economic zone. ${ }^{7}$ On 23 July 2010, the US Secretary of State, Hillary Clinton, stated at the ASEAn Regional Forum, that the settlement of disputes over the South China Sea is, 'related to US national interests'. Meanwhile, the United States has strengthened cooperation with Indonesia, Malaysia and Vietnam and has conducted several military exercises in the area. ${ }^{8}$ A recent event,

3 Xiaowei Lv, The Status of the South China Sea Dispute, Causes and Countermeasures, 7 ConTEMPORARY SOCIAL Horizons 76 (2009).

4 Regulations of continental shelf are Articles 76 and 77 of the Convention; regulations of the exclusive economic zone in the Convention are Articles 55, 56, and 57. The widths of the continental shelf and exclusive economic zones, according to the Convention, are 200 nautical miles.

5 Guoqiang Luo, The Multilateral Path to Solve the South China Sea Dispute and its ConstructionComment on "Declaration on the Conduct of Parties in the South China Sea", 25 LE GAL ForUM 94 (2010).

6 Hao Chu, The New Situation and New Developments of South China Sea Issue, 12 InternaTiONAL Data Information (China) 40 (2010).

7 Yen-Chiang Chang, Thinking about the Impeccable in the International Law of Sea, SHANDONG University LAW Review 161 (2010); Feng Dan, Liming Hu, and Shandan Zhou, New Trends in the South China Sea Dispute and China's Road to Protect Rights activists, 19 WORLD GEOGRAPHY 14 (2010).

8 Siqi Peng, New Trends in the South China Sea Issue, 18 Managers' Journal 45 (2010). 
which occurred on 20 July 2011, involved five Philippine congressmen landing on Thitu Island of the Spratly Islands, raising the Philippines flag and declaring sovereignty over the Thitu Island. In April 2012, the Gregorio del Pilar, the largest warship of the Philippines fleet, confronted two Chinese ocean surveillance ships at the Scarborough Shoal. The Philippine Navy was trying to arrest Chinese fishermen near the Scarborough Shoal but the arrest was prevented by the presence of Chinese surveillance boats. In June 2012, Vietnam launched the 'Oceans Act' in order to extend its maritime jurisdiction over Paracel and Spratly Islands. China had subsequently raised strong diplomatic protests against Vietnam's enactment. The release of the South China Sea Arbitration Award on 12 July 2016, has caused the South China Sea dispute to reach new heights. The events mentioned above amply demonstrate that States surrounding the South China Sea islands regard the rivalry for the South China Sea as a significant element in their strategy in resolving this issue has become of great concern for mainland China in the process of mainland China's growth process.

The South China Sea disputes are mainly focused on two issues. One is territorial sovereignty and the other is the maritime delimitation in the South China Sea. These two issues will be discussed separately, in the following parts of this article.

\section{Legal Basis for Each Claiming State}

Territorial sovereignty claims over the South China Sea islands have been made by six countries, namely, China, Vietnam, the Philippines, Malaysia, Brunei and Indonesia. In addition, Taiwan (China) also has made claims based upon special political factors, thus creating a six-nation-and-seven-party situation in the area. The Pratas Islands are garrisoned by Taiwan's (China) armed forces. The Macclesfield Bank is dominated by the practical control of the Philippines. The Paracel Islands are controlled by mainland China. The Spratly Islands are controlled by the following countries respectively, mainland China controls 7 reefs, Taiwan (China) 2, Vietnam 29, Philippines 8, Malaysia 5, with Brunei 2, and Indonesia $1 .{ }^{9}$

\section{$1 \quad$ Mainland China}

Mainland China claims sovereignty over the South China Sea islands, based upon the principle of occupation. Occupation is defined as when a State intentionally takes the territorial sovereignty of terra nullius. ${ }^{10}$ The object of

$9 \quad$ Luo, supra note 5 at 93.
$10 \quad$ TIEYA WANG, INTERNATIONAL LAW 171 (1995). 
occupation is terra nullius, which indicates that the territory has never before been discovered by human beings or over which, any prior sovereignty has been relinquished. ${ }^{11}$ According to traditional international law before the 18th Century, a State enjoyed the full sovereignty of the terra nullius, only by meeting the requirement of 'discovery'.12 Since the 18th Century, however, the dominant doctrine accepted by scholars and State practice has been that 'discovery' can only give the discovering country partial sovereignty and a country will only enjoy full sovereignty when it exercises effective occupation over the terra nullius and undertakes proper legislative, judicial or administrative action or performs its sovereignty, which is called, 'effectiveness principle.'13

As early as the and Century BC, during the ruling period of Emperor Wudi of the Han Dynasty, the Chinese began sailing in the South China Sea and they found the South China Sea islands through long-term sailing and production practices. Prior to this, the South China Sea islands have not been set foot upon, which meets the criterion of occupation, whereby land discovered should be deemed terra nullius. ${ }^{14}$ According to the principle of international law prior to the 18th Century and 'inter-temporal law',15 mainland China enjoys full sovereignty over the South China Sea islands, based on discovery. ${ }^{16}$

In addition, according to the view of modern international law, China's sovereignty over the South China Sea islands continues to exist. A series of activities

11 Shen, supra note 2 at 7.

12 Gerhard Von Glahn, Law Among Nations 311 (1986).

13 Robert Jennings and Arthur Watts (eds.), Oppenheim's International LAW 686-689 (1992); WANG, supra note 10 at 171; Shen, supra note 2 at 10-11; Gaoqiang Cai and Yang Gao, International Law Approach to Resolve the South China Sea Dispute, 35 Journal of Xiangtan University 40 (2011); Dexin Gu, The Application of Law of the sea in the South China Sea Dispute, 6 Strategy And MANag ement 97(1995); Xiaoxuan Zhang, The South China Sea Dispute between China and the Philippines and Legal Protection of Maritime Sovereignty, 5 Theoretical Circles 54 (2010).

$14 \mathrm{Gu}$, supra note 13 at 97; Zhang, supra note 13 at 54; Cai and Gao, supra note 13 at 39.

15 'Inter-temporal law' was first proposed by Huber, the arbitrator in the Island of Palmas Arbitration case in 1928. It indicates that 'a juridical fact must be appreciated in the light of the law contemporary with it and not of the law in force at the time when a dispute with regard to it rises or falls to be settled'. Huber further explained when there is a sovereignty dispute it should be determined whether there is a continued existence of right at the time dispute rises according to the progressed international law. After the Island of Palmas Arbitration case, 'Inter-temporal law' becomes a universally recognised principle of international law. Therefore, sovereignty of the South China Sea Islands should be determined according to the principles of international law at the time, that is, 'Acquisition of Property by Discovery' principle. See Lingling Sun, Analysis of the Sovereignty of the Diaoyu Islands from the Perspective of International Law, 2 JourNAL OF JAPANESE STU DiES 140-141 (2004); see also Yuanlong Huang, Concept of Inter-temporal Law in International Law, 2 Foreign LAW (2000).

Zhang, supra note 14 at 55 . 
conducted by mainland China, during various dynasties, such as naming the islands, exploitation, management, measurement, observation, inspection and stationing troops, shows the jurisdiction of mainland China, which is in compliance with the, 'principle of effective occupation.' ${ }^{17}$ 'It is worth noting that the effective occupation or control is a comparative concept, which means its criterion varies depending upon the nature of the terra nullius, involving its size, geographical location, climatic conditions and whether there is human inhabitation. ${ }^{\prime 18}$ For example, it is much easier to effectively occupy an uninhabited land, than a primitive tribal land because a State's troops may be stationed in the latter, while not in the former. ${ }^{19}$ The Clipperton Island Arbitration ${ }^{20}$ in 1931, between France and Clipperton Island, the Eastern Greenland Case ${ }^{21}$ in 1933 between Norway and East Greenland Denmark and advisory opinion of the International Court of Justice ${ }^{22}$ on the Status of Western Sahara, all reflect a common characteristic, that is, the criterion of effective occupation in international law for sparsely populated or uninhabited terra nullius is not significant. A tiny or symbolic activity of sovereignty declaration will enable a country to enjoy full sovereignty over the terra nullius, while continuous exercise of sovereign acts is not required. ${ }^{23}$ There are a large number of sparsely populated or uninhabited islands and reefs in the South China Sea islands. Even although mainland China has not exercised continuous sovereign acts, a series of acts, including naming and inspection, are deemed sufficient to constitute effective occupation.

From the 1830 s until the end of the Second World War, the South China Sea islands were invaded and occupied by France and Japan. In 1946, the Chinese government took over the Spratly Islands and Paracel Islands, based upon the statement of the Cairo Declaration and the Potsdam Declaration, and re-erected a sovereignty monument on the islands. ${ }^{24}$ The invasion and occupation by France and Japan of the South China Sea islands, cannot nullify the effect of territorial changes under international law, since the acquisition or occupation

17 There will not be an elaboration on the specific activities of China's exercise of jurisdiction in the South China Sea islands. See Shen, supra note 2; Gu, supra note 14; Zhao, supra note 2; Lihai Zhao, China's Indisputable Sovereignty over the South Sea Islands from International Law, 3 Journal of Peking University (Philosophy and Social SCIENCES) (1992). LAW 97 (1976).

19 Michael Ake hurst, A Modern Introduction to International LaW 143(1984).

20 Clipperton Island Arbitration (Fr. v. Mex.), 2 R.I.A.A. 1105, 26 AM. J. INT'L L. 390 (1931).

21 Legal Status of Eastern Greenland Case (Den. v. Nor.), 1933 P.C.I.J (Ser. A/B) No.53 (5 April).

22 Advisory Opinion on the Status of Western Sahara, 1975 I.C.J. Rep. 12, 43 (Oct. 16).

23 All cases cited above were taken from Shen, supra note 2 at 13.

24 Zhao, supra note 2 at 53 ; $\mathrm{Gu}$, supra note 14 at 98. 
of land by the threat or the use of force is illegal and will not be recognised in international law. ${ }^{25}$

From the analysis above, mainland China's claim to the South China Sea islands is based upon, 'the principle of occupation', which specifies terra nullius discovery and the principle of effective occupation. Meanwhile, before neighbouring States in the South China Sea claimed territorial sovereignty, mainland China had not been subject to intervention by any State, except the illegal invasion and occupation by France and Japan. These facts constitute powerful proof in international law of mainland China's to claim sovereignty over the South China Sea islands.

\section{$2 \quad$ The Philippines}

The Philippines claims sovereignty over the Scarborough Shoal and part of the Spratly Islands, for the following three reasons. Firstly, these islands are essential to the national security and economic development of the Philippines. Secondly, the Philippines is the State geographically closest to these islands. Thirdly, these islands are, 'ownerless islands'. ${ }^{26}$

There is no legal basis under international law as regards the first and second reasons. It is generally believed that there are five traditional ways of achieving territorial acquisition and changes in international law, these being occupation, accretion, prescription, cession and conquest. ${ }^{27}$ Security or economic development needs and the 'adjacency principle', are not recognised methods of territorial acquisition and change. As for the adjacency principle, the judgment of the International Court of Justice in the 1969 North Sea Continental Shelf case negated it and pointed out that the 'submarine areas did not appertain to the coastal State merely because they were near it'.28

The third reason is also unacceptable in international law. In 1948, Thomas Cloma and his team claimed to discover part of the Spratly Islands in the South China Sea and regarded these islands as, 'ownerless islands'. As mentioned above, however, as early as the Western Han Dynasty, mainland China had discovered and exercised jurisdiction continuously over the South China Sea islands. Meanwhile, mainland China has never had the intention of or acted to relinquish the South China Sea islands. The reasons offered by the Philippines are thus untenable. For a number of uninhabited islands in the Spratly Islands, especially those islands and reefs which appear and disappear with the ebb and

\footnotetext{
25 Wang, supra note 10 at 173.

26 Shen, supra note 2 at 59 .

27 Wang, supra note 10 at 171.

28 The Judgment of the ICJ Advisory Opinion and Command Summary (1948-1991), at 85, available at http://www.icj-cij.org/homepage/ch/files/sum_1948-1991.pdf; Zhao, supra note 2 at 55 .
} 
flow of the seas, make them impossible to permanently occupy but this does not mean that the sovereign States relinquished their claims on sovereignty. Whether a State relinquishes a claim to sovereignty depends on whether the State has the intention to relinquish it and has no intention to continue 'ownership'. It is evident that mainland China has always claimed its sovereignty over the South China Sea islands and no indication to relinquish has been given. ${ }^{29}$ The legal basis for the claim of the Philippines to have sovereignty over some of the South China Sea islands is thus untenable under international law.

\section{$3 \quad$ Vietnam}

Vietnam's claim on the Paracel Islands and Spratly Islands is mainly based on the following two points. Firstly, Vietnam claims its control over the Paracel Islands and Spratly Islands on the basis of history. Secondly, Vietnam inherited France's rights over the Spratly Islands.

The first reason proposed by Vietnam is that 'Hoang Sa' and 'Truong Sa', in its historic documents, are referred to as the 'Paracel Islands' and the 'Spratly Islands'. According to Chinese historical research, however, the aforementioned documents are referring merely to the islets and shoal along the coast of central and west Vietnam, rather than the Paracel Islands and the Spratly Islands. ${ }^{30}$ (See Figure 3.1) If the authenticity of this research is not questioned, it may be assumed that 'Hoang Sa' and 'Truong Sa' refer to the 'Paracel Islands' and the 'Spratly Island', then Vietnam was indeed the first to have discovered the South Sea islands. Mainland China has, however, claimed effective control over the South China Sea islands for up to 2000 years, while Vietnam only apparently began to claim sovereignty over islands in the 2oth century. Vietnam, however, should not be able to obtain sovereignty over the South China Sea islands because its action does not satisfy 'the principle of occupation' in international law. The result would thus appear to be that Vietnam cannot acquire sovereignty over the South China Sea islands.

In addition, before Vietnam's reunification in 1975, Vietnam had confirmed that the South China Sea islands have been a territory of mainland China. The 'Vietnam Atlas' and 'World Atlas', published by the Vietnam Bureau of Surveying and Mapping, even include the South China Sea islands within the territory of mainland China. ${ }^{31}$ Based on the abovementioned facts, Vietnam's

\footnotetext{
29 Shen, supra note 2 at 62.

3o Jinming Li, Vietnam's Hoang Sa and Truong Sa are not China's Paracel Islands and Spratly Islands, 2 CHINese Borderland History AND GeOgRAPHY (1997).

$31 \quad \mathrm{Gu}$, supra note 13 at 98.
} 


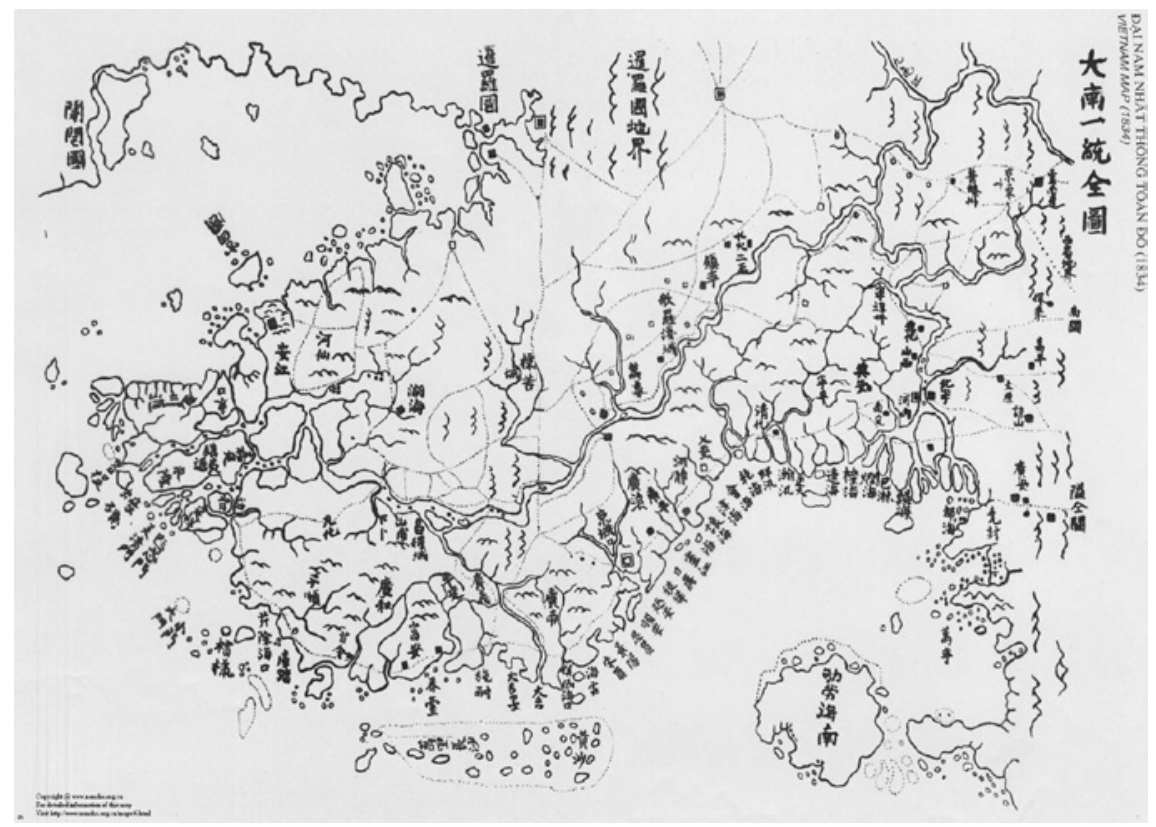

FIGURE 3.1 Vietnam Map, 1834.

SOURCE: WWW.NANSHA.ORG.CN, LAST VISITED: 2018/6/28

sovereignty claims over the South China Sea islands after 1975 are, in fact, in violation of estoppel in international law. ${ }^{32}$

As to the second reason proposed by Vietnam, as mentioned earlier, the French occupation of the Spratly Islands is considered a breach of international law. As a result, the apparently illegal activity cannot grant France legitimate rights over the South China Sea islands and inheritance of rights from France seems spurious.

\section{4}

Malaysia, Brunei, Indonesia

The sovereignty claims from these three States over the islands of the South China Sea are based upon the fact that these islands are within the 200nautical-mile exclusive economic zone or continental shelf. In fact, this proposition involves some apparent erroneous juxtaposition. UNCLOS specifies that delimitation of an exclusive economic zone and continental shelf is based upon the area being a part of a country's territory, which is embodied in the principle, 'the land dominates the sea'. It is manifested in the judgment of the International Court of Justice in the North Sea Continental Shelf Case as early 
as in 1969, that is, 'the rights of the coastal State to its continental shelf areas were based on its sovereignty over the land domain, of which the shelf area was the natural prolongation under the sea.' ${ }^{33}$ The result is that, a State cannot claim sovereignty over a land based upon claiming its exclusive ownership of an economic zone or continental shelf of the land, since this claim does not conform to the basic principle of international law.

\section{$5 \quad$ Taiwan (China)}

Taiwan (China) claims sovereignty over the South China Sea islands based upon reasons similar to those of mainland China, that is, 'the principle of occupation. ${ }^{34}$ Before 1950, mainland China, as a unified entity, occupied and exercised jurisdiction over the South China Sea islands; while after 1950, the split of mainland China and Taiwan (China) created the situation where the two parties exercised State functions in the South China Sea, respectively. Taiwan (China), as the 'The Republic of China', exercised jurisdiction over the South China Sea. For instance, the 'Pratas garrison area' and the 'Spratly garrison district', were set up in 1956. Ships were dispatched to inspect the Spratly Islands respectively in 1963 and 1966 . The Islands of Spratly were hosted by the Kaohsiung City Government in 1980 and a 'district office' was also set up. ${ }^{35}$ All these facts satisfy the elements of, 'the principle of occupation' as discussed above.

\section{$6 \quad$ Summary}

In summary, putting aside the political issues, both mainland China, as represented by the Government of the People's Republic of China and Taiwan (China) represented by the Republic of China, can exercise a strong claim to sovereignty over the South China Sea islands, based on the principle of occupation. Claims from other Southeast Asian States cannot, however, be supported by international law, according to the above analysis.

UNCLOS states in Articles 3, 57 and 76 that, measured from baselines, every State has the right to establish the breadth of its territorial sea up to a limit not exceeding 12 nautical miles, an exclusive economic zone not beyond 200

33 Yuan Guo, Analysis of the South China Sea Disputes in the Law of the Sea, 2 Northern LEgAL SCIENCE 136 (2009).

34 Hasjim Djalal, South China Sea Island Disputes, available at http://rmbr.nus.edu.sg/rbz/ biblio/s8/so8rbzoog-021.pdf

35 Available at http://lg2005.blog.hexun.com/2757179_d.html. 
nautical miles and a continental shelf, not exceeding $35^{\circ}$ nautical miles. Undoubtedly, the formulation of UNCLOS provides an authoritative reference for the world, in terms of maritime delimitation. Scholars have, nonetheless, commented that, "The provisions of the law of the sea have caused a new dispute similar to friend-or-foe dispute in Asia. No Asian State claims the limit of the continental shelf or the 200-nautical-mile exclusive economic zone without causing conflict with claims of other States". ${ }^{36}$ Furthermore, as mentioned above, some States misuse the relevant provisions of the continental shelf and exclusive economic zone stated in UNCLOS, to claim territorial sovereignty over the South China Sea islands, which aggravates the sovereignty dispute in the region and complicates the issue of maritime delimitation. In addition, the 'historic waters' issue and historical rights, have not been mentioned in detail in UNCLOS. Thus, accepting that there are provisions for the delimitation of straight baselines in Article 7, Paragraph 2, the exception of the historic gulf in Article 10, Paragraph 6 and the delimitation of the boundaries of territorial waters in Article 15, ${ }^{37}$ there is little explanation or definition of the concept of 'historic waters. These defects, to some extent, hinder the solution of the problem of the South China Sea. UNCLOS does, however, expressly provide in Articles 74 and 83 , that the delimitation of the exclusive economic zone and continental shelf between States with opposite or adjacent coasts, shall be effected by agreement on the basis of international law, as referred to in Article 38 of the Statute of the International Court of Justice, in order to achieve an equitable solution. This means that although the Convention does not provide specific methods to solve the problem of the maritime delimitation, it guides States to settle the dispute on the basis of basic principles and rules of international law. The rule of 'historic waters', as an international customary law referred to in Article 38 of the Statute of the International Court of Justice, should be considered by States in negotiation, as recognised and supported by UNCLOS. ${ }^{38}$

The concept of 'historic waters' has been proposed since the last century. In 1957, the Secretariat of the United Nations published a document entitled, 'Historic Bays', which specifies a State's 'historic rights', should include not only the 'historic bays' but also 'historic waters'. The so-called 'historic waters' are maritime areas which can be archipelagic waters, the water areas lying between an archipelago and the neighbouring mainland, as well as straits, estuaries and

36 George Lauriat, Chaos or Cooperation?, 199 Far Eastern Economic Review (1983); Guo, supra note 33 at 136 .

37 Jian He and Ao Wang, South China Sea Dispute in the View of International Law of the Sea, 1 ACAdemia In China 257(2008).

38 Cai and Gao, supra note 13 at 41. 
other similar bodies of water. ${ }^{39}$ The document entitled, 'Juridical Regime of Historic Waters, including Bays', published by the United Nations Secretariat in 1962, defines historic waters as, 'maritime areas which they considered vital to them without paying much attention to divergent and changing opinions about what general international law might prescribe with respect to the delimitation of the territorial sea. 40 The document also explicitly puts forward the elements of 'historic waters', as being a State exercising rights over the claimed, 'historic waters' effectively. The rights exercised effectively by a State over the waters should be continuous and the exercise of the rights should obtain acquiescence or tolerance of foreign States. ${ }^{41}$

The nine-dashed line, which mainland China has always maintained in the South China Sea delimitation, meets the requirements of 'historic waters.' ${ }^{42}$ Firstly, mainland China had discovered the South China Sea and exercised sovereign rights since the Western Han Dynasty. Secondly, the persistent exercise of sovereign rights over the South China Sea can be supported by several historical facts, as mentioned earlier. Thirdly, before the promulgation of

39 UN Secretariat, Historic Bays, UN doc A/CONF.13/1, 1 Official Records of United Nations Conference on the LaW of the Sea (1957) at 2. The original statement is: Historic rights are claimed not only in respect of bays, but also in respect of maritime areas which do not constitute bays, such as the waters of archipelagos and the water area lying between an archipelago and the neighboring mainland; historic rights are also claimed in respect of straits, estuaries and other similar bodies of water. There is a growing tendency to describe these areas as 'historic waters', not as 'historic bays'. Available at: http://untreaty.un.org/cod/diplomaticconferences/lawofthesea-1958/docs/ english/vol_I/4_A-CONF-13-1_PrepDocs_vol_I_e.pdf.

40 UN Secretariat, Juridical Regime of Historic Waters, including Bays, UN doc A/CN.4./143, 2 Yearbook of the International LaW Commission (1962) at 7. The original statement is: the concept of 'historic waters' has its roots in the historic fact that States through the ages claimed and maintained sovereignty over maritime areas, which they considered vital to them, paying little attention to divergent and changing opinions about what general international law might prescribe with respect to the delimitation of the territorial sea.

41 UN Secretariat, Juridical Regime of Historic Waters, including Bays, at 13-19. Ibid. The original statement is, "These factors are: (1) the exercise of authority over the area by the State claiming the historic right; (2) the continuity of this exercise of authority; (3) the attitude of foreign States".

42 There is a State's uncertain boundary marked by eleven-dotted discontinuous line South China Sea Islands Location Map published in 1947 by Division of Territory Administration, Department of the Interior of Chinese government after new China was formed, there was also such a line in the same location of the map published and audited by the relevant government department with the only difference being that eleven-dotted-line was changed to nine-dotted-line, which is often called the traditional boundary line. Because the line is U-shaped, it is also known as U-shaped line. Cited from Cai and Gao, supra note 13 at 42 . 
UNCLOS, the sovereign right of mainland China over the South China Sea had not been subjected to any State's opposition for many years. The result is that, based on the particularity of 'historic waters', mainland China should have exclusive sovereign rights over the South China Sea, not being restricted by the relevant delimitation provisions of UNCLOS. The 'Map of Location of the South China Sea Islands', published by the Republic of China (refers to Taiwan (China), hereinafter ROC) in 1947, creates the U-shaped line whose legal nature is that the islands or groups of islands enclosed by a U-shaped line are part of territories of the State of China. (see Figure 3.2) As to the legal nature of the maritime area enclosed by the U-shaped line, the Policy Guidelines for the South China Sea adopted by the Executive Yuan of Taiwan (China) on 13 April 1993, clarifies that, 'the South China Sea area within the historic waters limit is the maritime area under the jurisdiction of Taiwan (China), where Taiwan (China) possesses all rights and interests. ${ }^{3}$ As to U-shaped line, the position of the mainland China is similar to that of Taiwan (China). Mainland China stated in Notes Verbale in response to the Malaysia/Vietnam Joint Submission and the Vietnam Submission that, 'China has indisputable sovereignty over the islands in the South China Sea and the adjacent waters, and enjoys sovereign rights and jurisdiction over the relevant waters, as well as the seabed and subsoil thereof'.44 (see Figure 3.3) It is, therefore, not difficult to conclude that mainland China and Taiwan (China) stand on the same legal ground with respect to the South China Sea waters.

\section{Possible Breakthrough Regarding Existing Difficulties}

From the analysis mentioned above, based on international law, mainland China enjoys territorial sovereignty over the South China Sea Islands based on, 'the principle of occupation' and enjoys the historic sovereign rights over the South China Sea, based on the rule of 'historic waters'. Claims proposed by neighbouring States of the South China Sea concerning the delimitation of South China Sea islands are difficult to find legal ground. The delimitation of the South China Sea can, however, be advocated in international law. From this perspective, once the dispute is submitted by disputing States to international arbitration

43 See Michael Sheng-Ti Gau, The U-Shaped Line and a Categorization of the Ocean Disputes in the South China Sea, 43 Ocean Development \& International LaW $5^{8}$ (2012). Also see, The Republic of China, South China Sea Policy Guidelines, attached as an appendix to Kuan-Ming Sun, Policy of the Republic of China Towards the South China Sea, 19 MARINe Policy 408 (1995).

PRC, Letter CML/17/2009, 7 May 2009; and Letter, CML/18/2009, 7 May 2009. 


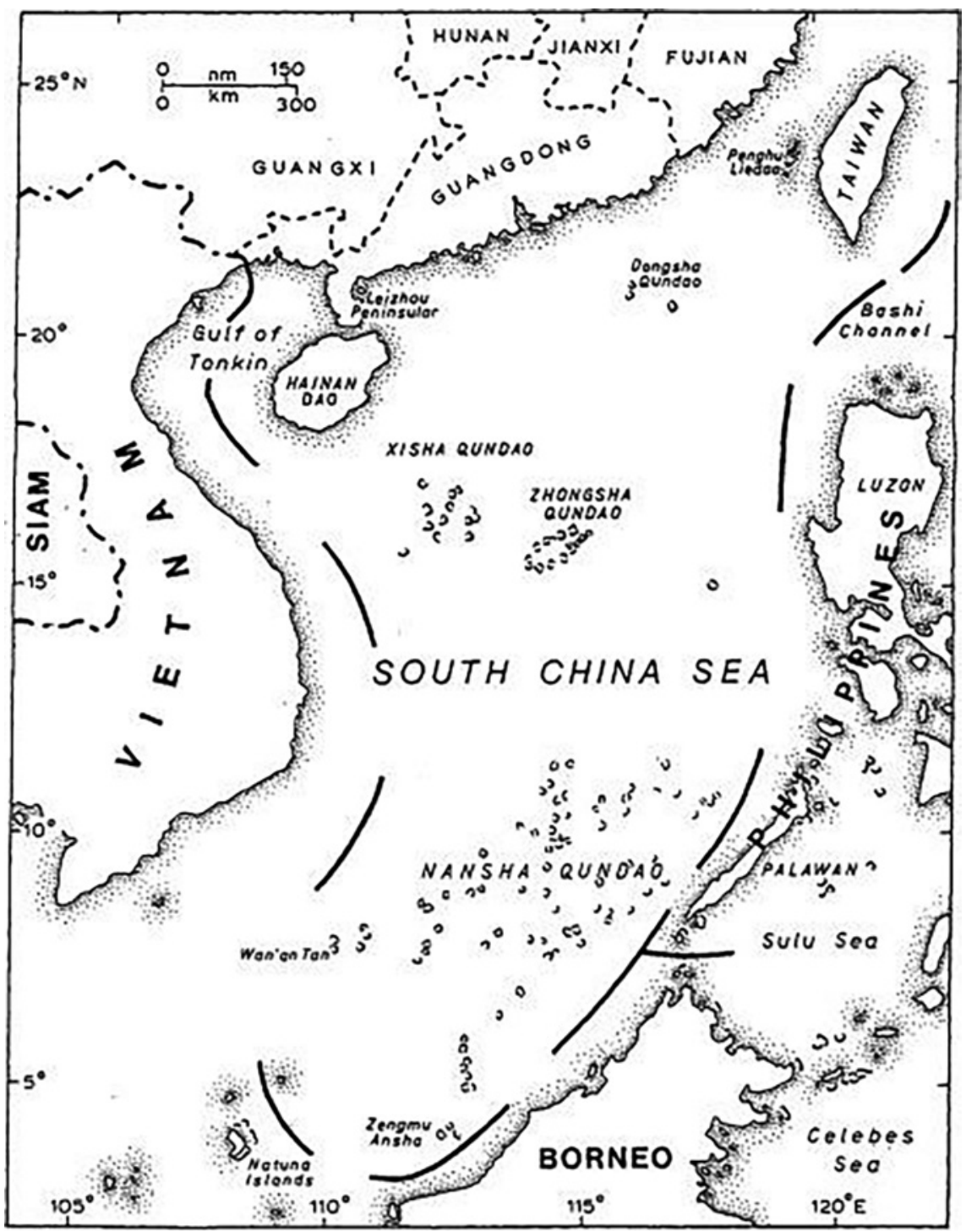

FIGURE 3.2 Map of location of the South China Sea islands, Ministry of the Interior of the Republic of China, 1947.

SOURCE: MINISTRY OF THE INTERIOR, COMPILATION OF HISTORICAL ARCHIVES ON THE SOUTHERN TERRITORIES OF THE REPUBLIC OF CHINA, (2015), P. 51

institutions or the International Court of Justice, mainland China has a great advantage. This solution is also relatively fair and complete. Mainland China has, however, not accepted the compulsory jurisdiction of the International Court of Justice. Furthermore, there is no relevant treaty between mainland 


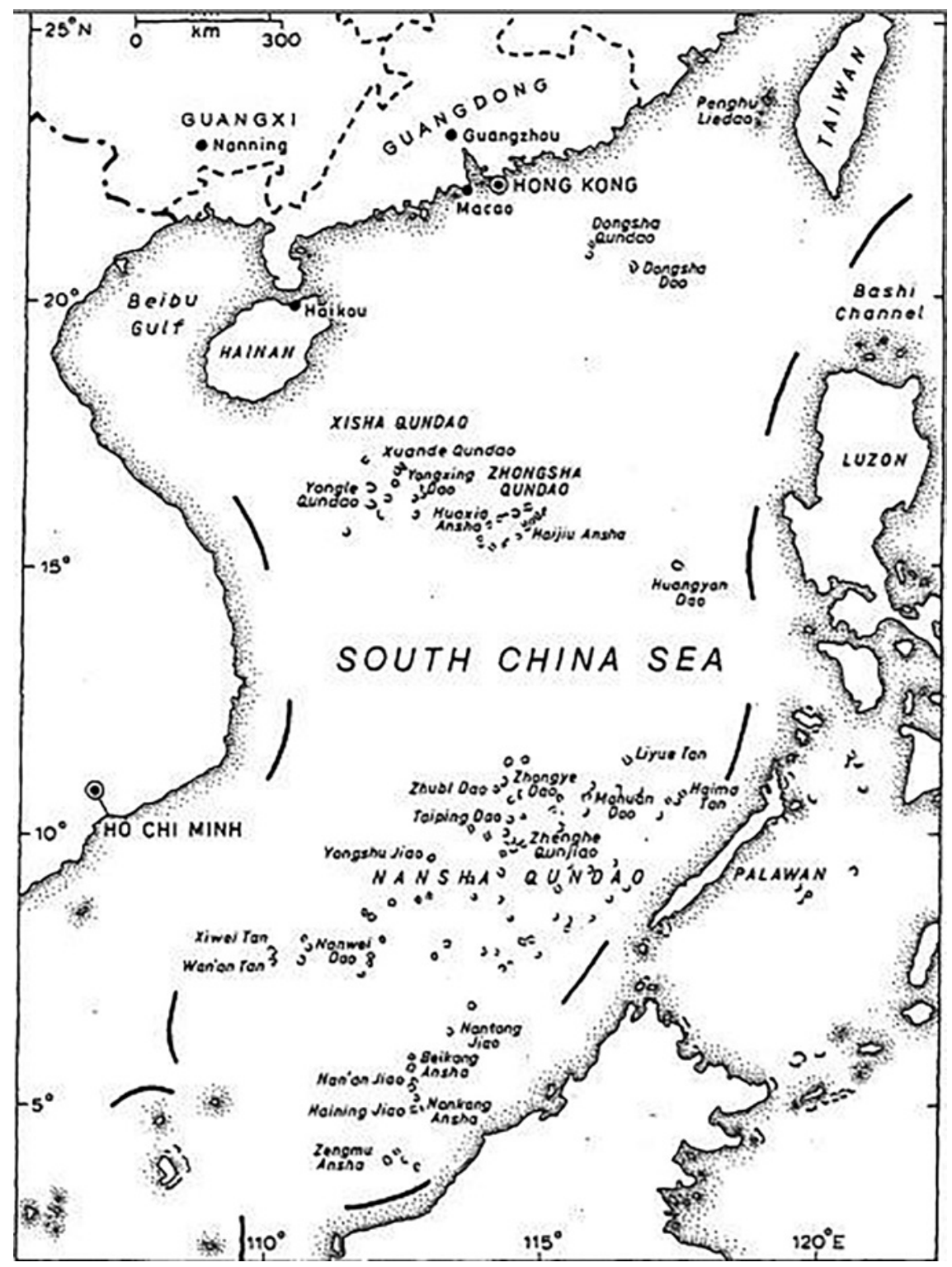

FIGURE 3.3 Nine dotted lines claimed by the People's Republic of China in the South China Sea (See Notification of the PRC dated 7 May 2009 to challenge the Joint Submission of Vietnam and Malaysia to the CLCS dated 6 May 2009. The lines are indicated in the map.)

SOURCE: HTTP://WWW.UN.ORG/DEPTS/LOS/CLCS_NEW/SUBMISSIONS_FILES/ MYSVNM33_09/CHN_2009RE_MYS_VNM_E 
China and other disputing States, to authorize such a jurisdiction or arbitration agreement. Mainland China is not willing to let this issue to be judged by a third party, primarily because it has always maintained the South China Sea islands and the South China Sea, are among its inherent territories, which thus cannot be judged. ${ }^{45}$ This position can be seen from the response of mainland China to the fact that the Philippines has submitted the two States' disputes over the Spratly Islands to the International Tribunal for the Law of the Sea. ${ }^{46}$

Mainland China tends to solve South China Sea disputes through bilateral negotiations, which can be seen from the fact that mainland China and ASEAN signed the Declaration on the Conduct of Parties in the South China Sea in 2002. ${ }^{47}$ According to Article 4 of the Declaration, "The Parties concerned undertake to resolve their territorial and jurisdictional disputes by peaceful means, without resorting to the threat or use of force, through friendly consultations and negotiations by sovereign States directly concerned, in accordance with universally recognised principles of international law, including the 1982 UN Convention on the Law of the Sea". Article 5 of the Declaration provides that "The Parties undertake to exercise self-restraint in the conduct of activities that would complicate or escalate disputes and affect peace and stability including, among others, refraining from action of inhabiting on the presently uninhabited islands, reefs, shoals, cays, and other features and to handle their differences in a constructive manner". However, the situation of the South China Sea dispute becomes increasingly complex and internationalised in recent years, which shows that the Declaration has failed to play its role originally envisaged. This indicates that with increasingly prominent contradictions and differences among parties of the South China Sea, whether negotiations are multilateral or bilateral, it is very difficult for the various disputing parties to reach an agreement on the territorial sovereignty of the South China Sea Islands and delimitation of the South China Sea waters. That is why mainland China has strongly advocated "putting aside disputes and seeking joint development". However, according to the analysis of Professor Guocai Zhao, the prerequisite for joint development is that each State should recognise the existence of the dispute, reach a consensus on the scope of the areas in dispute and confirm that their occupation of the islands and reefs cannot be regarded

45 Guocai Zhao, Cross-strait Cooperation to Develop Oil and Gas Resources in the South China Sea from the Point of View of International Law, 56 Special Issue of Martial LaW 62 (2010).

46 China's response to the Philippines' advice to submit the South China Sea to the International Tribunal for the Law of the Sea, available at http://gb.chinareviewnews.com/doc $/ 1017 / 6 / 5 / 3 / 101765366 . h$ tml coluid $=7 \&$ kindid $=0 \&$ docid $=101765366 \&$ mdate $=0713164945$. 
as recognition of its territorial sovereignty. However, it is difficult for each State to make concession to the last point in negotiations. For instance, Vietnam insists on the priority of delimitation over of discussion of joint development. Meanwhile, there are different understandings of States about the way for joint development. ${ }^{48}$ Therefore, to achieve the target to develop the resources of the South China Sea jointly with Southeast Asian States can be described as difficult and will be a long process.

However, it is worth noting that there is plenty of space and possibilities for the cross-strait cooperation in resource development of the South China Sea. First, mainland China's and Taiwan's (China) positions on the South China Sea are the same in essence. As mentioned above, both sides have denied sovereignty claims of various States of Southeast Asia. This position lays a foundation for both parties to avoid sensitive political topics, cooperate unanimously to resist externally. Second, Taiwan's (China) "Blue Ocean Strategy" which advocates "shelving disputes, keeping peaceful and reciprocal, and seeking joint development"49 is consistent with mainland China's principle "putting aside disputes and seeking joint development", which also guarantees cross-strait cooperation. Third, since 1994, the two parties have already launched a series of exploration cooperation programme of oil and gas in the Taiwan Strait. Mainland China's National Offshore Oil Corporation and Taiwan's (China) Chinese Petroleum Corporation have negotiated for many times, worked out agreements and established the principle of "keeping reciprocal and mutually beneficial, and putting aside sovereignty problem". ${ }^{0}$ Cross-strait cooperation in the South China Sea can draw lessons from the cooperation in the Taiwan Strait to exploit oil and gas.

Therefore, the two sides can fully draw lesson from the cooperation mechanism of oil and gas exploitation in the Taiwan Strait, to avoid the relevant political factors and to develop the South China Sea resources jointly. To specify, the two sides can divide resources into two parts which are renewable resources such as fishery resources, and non-renewable resources such as oil and natural gas. The two sides can start from the less controversial negotiation of fishery resources to conclude an agreement of joint development, and then gradually expand to the relatively more complex negotiation of the joint development of oil, gas and other non-renewable resources and conclude an agreement different from the development of fisheries resources. Such separate regulation reflects the characteristics of different resources in a better way

48 Zhao, supra note 45 at $64-65$.

49 Zhao, supra note 45 at 66.

5o Ibid. 
and accelerates the pace of cooperation. To a certain extent, the cooperation of mainland China and Taiwan (China) in the South China Sea can play a role to resist unanimously, to suppress disputing States in Southeast Asia, and to achieve and safeguard maritime rights and interests in the South China Sea in a better way. In addition, with the further deepening of cross-strait cooperation, the two sides can also cooperate and exert pressure on disputing States in Southeast Asia to promote the negotiation of resource cooperation and joint exploitation as soon as possible.

\section{v Conclusion}

From the perspective of international law, there is strong legal basis for mainland China to claim sovereignty over the South China Sea Islands and sovereign rights over the surrounding waters. Facing the increasingly intensified situation in the South China Sea, "putting aside disputes and seeking joint development" is the better solution to meet the interests of all States; however, it is still difficult to achieve this goal.

From the analysis mentioned above, based on the common interests of mainland China and Taiwan (China) and the positions of the various claimant States in the South China Sea disputes, there is a great space in the joint development of the South China Sea. Therefore, the first action should be to promote the cooperation of the two sides in resource development of the South China Sea. At the same time, pressures from the two sides on Southeast Asian States can also promote cooperation and negotiations among the disputing States as soon as possible, which will further ease the situation in the South China Sea, and achieve a win-win situation. 